\title{
PEMBERDAYAAN WANITA TANI MELALUI PRODUKSI DAN MANAJEMEN PRODUKSI KERUPUK BATANG PISANG DI JENAWI KARANGANYAR
}

\author{
Retno Rosariastuti, Sumani, Aktavia Herawati \\ Program Studi Ilmu Tanah, Fakultas Pertanian, Universitas Sebelas Maret \\ E-mail: retnobs@staff.uns.ac.id
}

\begin{abstract}
Jenawi Subdistrict was one of the sub-districts that located in the Karanganyar Regency area which has the location of the pilot project for planting banana plants as a product of tissue culture form Agriculture Faculty, Universitas Sebelas Maret. There are many banana plants that grow well with abundant fruit production. One part of the banana plant that has not been utilized was the inside of a white banana stem called the heart of a banana stem or ares. Ares can be processed into healthy food products that have high fiber content, namely crackers. The technology or method to made crackers has never been done. This activity aims to produced ares crackers with various shapes and flavors and analyzed the economic feasibility of the business. The main objective of this activity was to improve the empowerment of women farmers as a companion husband who has the ability to help increase the family's economy by producing crackers ares. This activity was a side activity that can be done at home or together in a group of women farmers. The method used participatory rural appraisal which emphasizes innovation and technology in making ares crackers using simple technology. The program's hope the technology was easy to adopt and sustainable because it uses simple technology. The activity begins with an explanation of the methods and stages of making crackers. The activity continued with training in economic analysis of cracker products. The results of economic analysis showed that to produce $20 \mathrm{~kg}$ crackers required a fixed cost of production of Rp. 33,330, - and variable costs of Rp. 564,700. Total revenue from $20 \mathrm{~kg}$ crackers was $R p$. 920,000, - so that the total income was Rp. 321,970, -. Based on this value, the R / C Ratio value was 1.53 (feasible), the B / C Ratio was 0.53 (feasible). So that based on economic analysis, banana stem crackers or ares crackers business is feasible to be cultivated and developed.
\end{abstract}

Keywords : ares, crackers, women farmers, empowerment, $R / C$ ratio, $B / C$ ratio

\section{PENDAHULUAN}

Tanaman pisang (Musa paradisiaca L.) merupakan tumbuhan yang banyak tumbuh di daerah tropis, karena menyukai iklim panas dan memerlukan matahari penuh. Tanaman ini dapat tumbuh di tanah yang cukup air pada daerah dengan ketinggian sampai 2000 meter di atas permukaan laut. Pisang merupakan komoditas buah prioritas di Indonesia. Terbukti pada tahun 2014, produksi buah pisang mencapai 6,8 juta ton yang merupakan penyumbang produksi buah terbesar (Direktorat Jenderal Hortikultura, 2015) dan meningkat menjadi 7,3 ton pada tahun 2015 (Kementerian Pertanian, 2016). Berdasarkan kelas kesesuaian lahan, Kecamatan Jenawi memiliki kelas cukup sesuai (S2) untuk pengembangan tanaman pisang khususnya di Desa Trengguli, Sidomukti, Balong, Lempong, Menjing dan Seloromo. Daerah ini memiliki temperatur tertinggi sekitar $22.6{ }^{\circ} \mathrm{C}$ dan curah hujan terendah 3,333 mm/tahun. Sehingga area ini sangat potensial untuk pengembangan pisang (Mujiyo et al., 2017).

Buah pisang dapat dikelompokkan menjadi beberapa kelompok berdasarkan manfaatnya. Kelompok pertama adalah Musa 
sapientum yang termasuk pisang buah meja. Kelompok ini lebih enak dimakan segar. Anggota kelompok ini antara lain: pisang ambon, ambon lumut, raja, raja sereh, mas, susu, dan barangan. Kelompok kedua adalah Musa paradisiaca (plantain). Buah pisang pada kelompok ini lebih enak setelah diolah terlebih dahulu. Anggota kelompok ini antara lain: pisang tanduk, oli, nangka, kapas, batu, dan kepok. Kelompok ketiga adalah Musa brachycarpa, yaitu jenis pisang yang berbiji seperti pisang batu, disebut juga pisang klutuk. Kelompok keempat adalah Musa texilis, yaitu jenis pisang penghasil serat seperti pisang manila (Redaksi Trubus, 2006).

Beberapa manfaat buah pisang pada kesehatan manusia antara lain: melumas (lubricate) usus, penawar racun, penurun panas (antipiretik), antiradang, peluruh kencing (diuretik), laksatif dingin dan lainlain. Buah pisang mengandung banyak vitamin diantaranya vitamin $C$ dan $D$ serta mineral kalsium, kalium dan fosfor, sehingga sangat bermanfaat dalam menjaga kesehatan manusia. Pisang bermanfaat untuk meningkatkan daya tahan tubuh, sehingga mengurangi resiko terserang penyakit. Tingginya nilai gizi buah pisang disertai seratnya yang halus menyebabkan buah ini sangat baik digunakan sebagai makanan bayi, balita maupun lansia. Buah pisang juga baik untuk para penderita sakit yang sedang dalam proses penyembuhan. Kandungan karbohidrat (gula) dan fosfor dalam buah pisang akan membuat yang mengkonsumsinya tahan lapar, namun bagi penderita tukak lambung dan asam lambung berlebihan, disarankan untuk tidak mengkonsumsi buah pisang masak secara berlebihan, terlebih ketika perut dalam keadaan kosong (Afandi 2013; Anonim 2015).

Bagian tanaman pisang yang dapat dimanfaatkan selain buahnya adalah daun, batang pisang, jantung pisang, bonggol pisang, akar pisang dan kulit buah pisang. Daun pisang dikenal sebagai bahan pembungkus makanan sejak lama. Selain itu sebagian masyarakat memanfaatkan daun pisang yang masih muda untuk campuran masakan. Daun pisang juga sering digunakan sebagai bagian dari ritual budaya, misal sebagai alas pada penyajian nasi tumpeng atau sesaji. Batang pisang (gedebog) dapat digunakan sebagai bahan pembuat rakit, mainan anak-anak, sarana ritual budaya (misal alat untuk menancapkan wayang kulit), seratnya sebagai bahan dasar industri tekstil. Bagian dalam dari batang pisang, dikenal sebagai hati batang pisang, sering dimanfaatkan sebagai bahan makanan yaitu dimasak sebagai sayur. Jantung (bunga) pisang dapat digunakan sebagai bahan makanan olahan dan sarana pembuatan mainan anak-anak. Bila bagian tengah bonggol pisang yang masih berada di tanah dilubangi, akan mengeluarkan air, yang mana air ini sering dimanfaatkan sebagai penyubur rambut, dan antiseptik pada luka. Akar pisang dan hati batang pisang dapat digunakan sebagai sumber mikroorganisma pada pembuatan pupuk hayati. Kulit buah pisang dapat dimanfaatkan sebagai campuran masakan (Suyanti dan A. Supriyadi, 2008).

Berdasarkan uraian tersebut, diketahui begitu banyak manfaat dari tanaman pisang, namun sebenarnya masih banyak potensi pemanfaatan dari tanaman pisang, utamanya pada bagian hati batang pisang atau ares. Ares sangat besar manfaatnya untuk digunakan sebagai bahan dasar makanan olahan, yaitu sebagai bahan pencampur pembuatan kerupuk. Kerupuk ares saat ini belum dikenal secara luas oleh masyarakat, padahal dengan cara memasak dan pemberian bumbu yang tepat, akan tercipta kerupuk ares yang enak dan prospektif dikembangkan sebagai alternatif produk makanan baru. Tingginya serat pada hati batang pisang, akan menyebabkan produk makanan tersebut memiliki kandungan serat yang tinggi, 
sehingga baik untuk pencernaan. Diversifikasi pemanfaatan hati batang pisang sebagai bahan dasar pembuatan makanan olahan akan meningkatkan nilai ekonomis dari tanaman pisang. Apalagi jika teknologi yang digunakan tergolong sederhana. Untuk itu perlu pengenalan cara pembuatan kerupuk hati batang pisang ini kepada masyarakat yang di lingkungan tempat tinggalnya banyak tumbuh tanaman pisang. Sehingga akan terjadi pemanfaatan barang/produk yang sebelumnya tidak bernilai ekonomis menjadi bernilai ekonomis tinggi.

Kecamatan Jenawi, Kab. Karanganyar, Propinsi Jawa Tengah merupakan salah satu wilayah yang banyak ditumbuhi tanaman pisang. Fakultas Pertanian Universitas Sebelas Maret telah menggunakan wilayah ini sebagai pilot project penanaman pisang hasil kultur jaringan. Olahan buah pisang sudah sangat banyak, sedangkan bagian lain dari pohon pisang seperti batang hati pisang belum termanfaatkan. Oleh sebab itu dibutuhkan inovasi baru dalam memanfaatkan hati batang pisang sebagai bahan dasar pembuatan kerupuk. Sehingga usaha produksi kerupuk batang hati pisang dapat menjadi tambahan sumber pendapatan wanita tani di Jenawi. Pendapatan masyarakat meningkat melalui usaha/produksi kerupuk hati batang pisang. Kegiatan pengabdian bertujuan untuk memproduksi kerupuk hati batang pisang, menambah berbagai kreasi rasa kerupuk hati batang pisang, dan menganalisis usaha ekonomi kerupuk apakah layak untuk kegiatan ini, adalah KWT Mukti Rahayu dan KWT Ngudi Rejeki. Tujuan akhir kegiatan ini adalah untuk memberdayakan perempuan di wilayah Jenawi melalui manajemen produksi olahan kerupuk sebagai bentuk upaya untuk meningkatkan ekonomi keluarga dan masyarakat. dikembangkan. Yang menjadi sasaran

\section{METODE}

Metode yang digunakan adalah partisipasi masyarakat (participatory rural appraisal). Metoda pendekatan ini menekankan pada inovasi dan teknologi pembuatan kerupuk berbahan hati batang pisang dengan menggunakan teknologi sederhana. Penggunaan teknologi sederhana bertujuan supaya teknologi ini lebih adaptif dan inovatif sehingga tingkat adopsi masyarakat tinggi dan aspek keberlanjutan pasca kegiatan dapat berlangsung. Kegiatan dimulai dengan penjelasan mengenai cara dan tahap-tahap pembuatan kerupuk berbahan hati batang pisang. Kegiatan dilanjutkan dengan pelatihan analisis ekonomis produk kerupuk hati batang pisang dan menganalisis apakah usaha kerupuk hati pisang ini layak dikembangkan.

Tata laksana kegiatan meliputi survei pendahuluan guna mengetahui wilayah yang memiliki banyak tanaman pisang, berkoordinasi dengan perangkat desa dalam menentukan waktu, tempat dan materi yang dibutuhkan, persiapan peralatan dan perlengkapan pelatihan, penyusunan modul/materi pelatihan, praktek pembuatan kerupuk hati batang pisang serta melakukan analisis ekonomi. Bahan-bahan yang diguanakan untuk membuat kerupuk hati pisang yaitu: hati batang pisang, yaitu batang pisang bagian paling dalam yang berwarna putih dengan ukuran $1 \mathrm{~m}$, tepung tapioka sebanyak $1 \mathrm{~kg}$, air secukupnya, bumbu berupa bawang putih, merica, garam, gula, bahan penyedap secukupnya. Alat yang digunakan adalah blender, panci untuk mengukus (dandang), kain untuk menyaring, loyang untuk menjemur, wajan untuk menggoreng, telenan, dan pisau.

Cara pembuatan kerupuk hati batang pisang: (1) hati batang pisang dicuci bersih, kemudian iris kecil-kecil, kemudian dihaluskan menggunakan blender, (2) hati batang pisang yang sudah halus disaring menggunakan kain saring yang halus (kain 
katun), (3) ampas hati batang pisang dicampur tepung terigu dan tepung tapioka serta bumbu yang sudah dihaluskan lebih dahulu, (4) semua bahan yang sudah tercampur diuleni sampai membentuk gumpalan yang liat berbentuk silinder, kemudian bungkus menggunakan daun pisang atau plastik. Ini merupakan bahan dasar kerupuk hati batang pisang. Jika terlalu kering dapat ditambah air seperlunya, (5) kukus selama kurang lebih 45 menit (sampai matang), kemudian dinginkan, (6) selanjutnya bahan dasar diiris tipis, lalu dijemur di bawah panas matahari, (7) bahan dasar kerupuk siap digoreng menjadi kerupuk hati batang pisang dan siap dikonsumsi. Pelatihan analisis ekonomis produk kerupuk hati batang pisang dilakukan dengan metode center learning, dengan pengabdi sebagai narasumber utama. Materi disampaikan secara langsung kepada para ibu anggota KWT, diakhiri dengan diskusi dan tanya jawab. Pada sesi tanya jawab dilakukan penggalian terhadap permasalahan yang dihadapi terutama dalam rangka meningkatkan produksi kerupuk hati batang pisang.

\section{HASIL DAN PEMBAHASAN}

Kegiatan pengabdian di Kecamatan Jenawi ini bertujuan untuk menginisiasi para anggota wanita tani yang tergabung dalam Kelompok Wanita Tani Rejeki Mandiri dan Mukti Rahayu untuk memanfaatkan hati batang pisang. Di wilayah ini hati batang pisang belum dimanfaatkan, bahkan hati batang pisang dianggap sebagai limbah atau kotoran yang tidak bernilai. Pelatihan pembuatan kerupuk berbahan hati batang pisang menjadi inovasi yang cukup menjanjikan. Hal ini karena hati batang pisang mengandung serat yang cukup tinggi sehingga produk kerupuk yang dihasilkan memiliki nilai lebih. Selain itu penggunaan teknologi yang sederhana untuk memproduksi hati batang pisang menjadi produk kerupuk berkadar serat tinggi mempunyai daya tarik untuk dilakukan. Sehingga pengabdi berharap teknologi yang sederhana ini dapat dengan mudah diadopsi oleh peserta dan dapat dilakukan secara berkelanjutan.

Setelah mahir memproduksi kerupuk, peserta diberi keterampilan untuk menghitung laba-rugi atas usaha kerupuk hati batang pisang. Keterampilan diberikan melalui pelatihan manajemen produksi kerupuk dengan menghitung analisis ekonomi usaha. Peserta pelatihan sekitar 50 wanita tani yang tergabung dalam 2 Kelompok Wanita Tani (KWT) Rejeki Mandiri dan Mukti Rahayu. Peserta sangat berantusias mengikuti pelatihan ini terbukti dengan semangat mereka untuk mendapat ilmu baru yaitu cara mengolah batang pisang menjadi barang/makanan yang bernilai ekonomis dan manajemen produksi yang bagus, sehingga menghindarkan mereka dari kerugian. Pelatihan ini juga dihadiri oleh pamong desa dan Penyuluh Pertanian Kec. Jenawi.
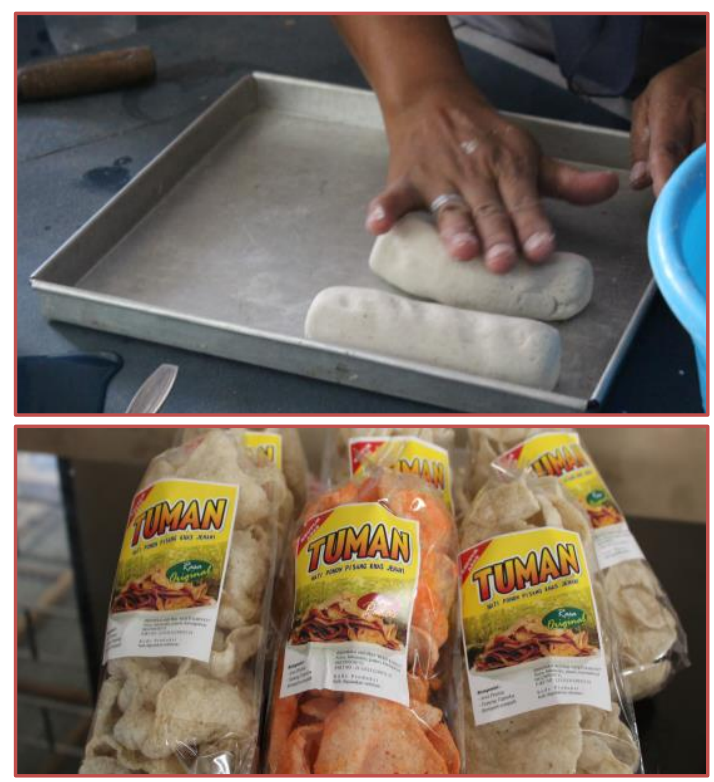

Gambar 1a. Proses Pembuatan kerupuk (b). Produk kerupuk siap jual

Setelah pelatihan, para peserta berkumpul dan saling bertukar informasi tentang permasalahan yang mereka jumpai Copyright $(2019$ PRIMA: Journal of Community Empowering and Services e-ISSN: 2579-5074 
dan peralatan yang dibutuhkan untuk meningkatkan produksi kerupuk. Berdasarkan monitoring dan evaluasi yang telah dilakukan, kendala yang dihadapi oleh anggota Kelompok Wanita Tani Rejeki Mandiri dan Mukti Rahayu adalah ketidakkonsistenan dalam bentuk dan ukuran kerupuk serta packaging produk. Oleh karena itu dibutuhkan alat pemotong/perajang adonan kerupuk sehingga kerupuk mentah mempunyai bentuk dan ukuran yang sama. Berdasarkan hal tersebut, tim pengabdi beserta ketua kelompok tani bersama-sama meninjau industri kerajinan pembuatan alat rumah tangga berupa perajang kerupuk. Setelah melihat spesifikasi dan kesesuaian hasil, disepakati memesan alat perajang kerupuk. Evaluasi kegiatan pengabdian dilakukan bersamaan dengan penyerahan bantuan alat berupa perajang kerupuk, alat penggoreng dan kompor. Kegiatan ini diikuti oleh seluruh pengabdi dan seluruh anggota kelompok tani. Pelatihan menghitung analisis ekonomis kerupuk hati batang pisang merupakan kegiatan untuk menghitung kelayakan usaha kerupuk. Dalam perhitungan ini, diasumsikan bahwa satu kali produksi menghasilkan sebanyak $20 \mathrm{~kg}$ kerupuk hati batang pisang.

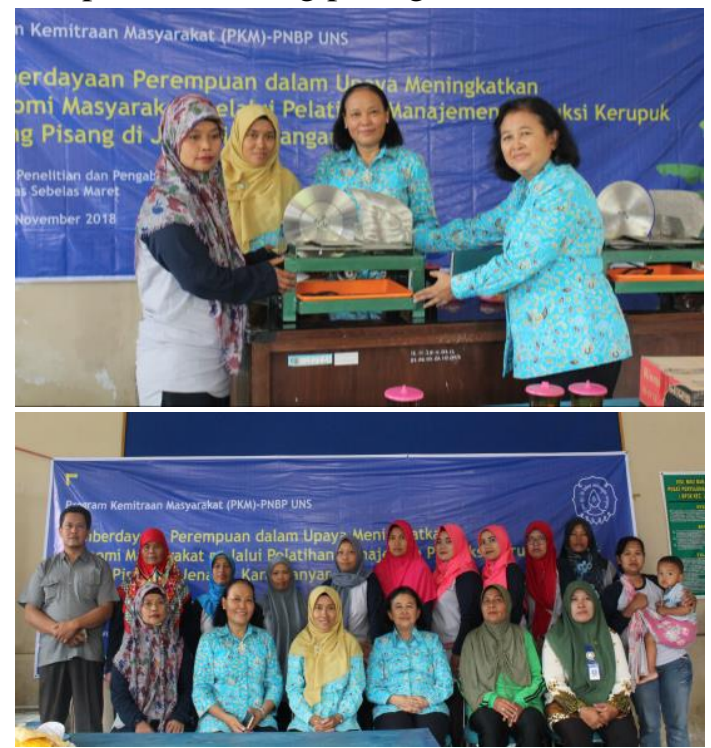

Gambar 2a. Serah terima bantuan alat perajang, (b) Foto bersama pengabdi dan peserta

Total biaya tetap yang digunakan untuk produksi kerupuk hati pisang sebanyak 20kg dalam 1 kali produksi yaitu sebesar Rp. 33.330,-. Biaya tersebut cukup murah karena hasil yang didapatkan berdasarkan penyusutan dari nilai ekonomis setiap alatalatnya.

Tabel 1. Analisis Kebutuhan alat untuk produksi kerupuk batang hati pisang

\begin{tabular}{llcccccr}
\hline No & \multicolumn{1}{c}{ Uraian } & $\begin{array}{c}\text { Vol } \\
\text { um } \\
\mathbf{e}\end{array}$ & Satuan & $\begin{array}{c}\text { Harga } \\
\text { Satuan } \\
(\mathbf{R p})\end{array}$ & $\begin{array}{c}\text { Jumlah } \\
\text { Harga } \\
(\mathbf{R p})\end{array}$ & $\begin{array}{c}\text { Umur } \\
\text { Ekonomis } \\
(\text { Bulan) }\end{array}$ & $\begin{array}{r}\text { Biaya } \\
\text { Penyusutan/ } \\
\text { 1 Bulan (Rp) }\end{array}$ \\
\hline 1 & Kompor Gas 2 Tungku & 1 & Buah & 375.000 & 375.000 & 60 & 6.250 \\
2 & Blender & 1 & Buah & 175.000 & 175.000 & 60 & 2.916 \\
3 & Wajan Besar & 1 & Buah & 150.000 & 150.000 & 48 & 3.125 \\
4 & Dandang & 1 & Buah & 120.000 & 120.000 & 36 & 3.333 \\
5 & Baskom & 4 & Buah & 15.000 & 60.000 & 24 & 2.500 \\
6 & Pisau & 3 & Buah & 15.000 & 45.000 & 36 & 1.250 \\
7 & Tampah Bambu & 5 & Buah & 20.000 & 100.000 & 24 & 4.166 \\
8 & Sotil & 1 & Buah & 15.000 & 15.000 & 24 & 625 \\
9 & Serok & 1 & Buah & 15.000 & 15.000 & 24 & 625 \\
10 & Timbangan Analog 2kg & 1 & Buah & 50.000 & 50.000 & 48 & 1.041 \\
11 & Kain Penyaring & 2 & Buah & 10.000 & 20.000 & 6 & 3.333 \\
12 & Mesin Press Plastik & 1 & Buah & 150.000 & 150.000 & 36 & 4.166 \\
\hline
\end{tabular}


Tabel 2. Biaya Variabel untuk pembuatan Kerupuk untuk 1 kali produksi sebanyak 20kg

\begin{tabular}{|c|c|c|c|c|c|}
\hline No & Keterangan & Vol. & Satuan & $\begin{array}{c}\text { Harga } \\
\text { Satuan } \\
(\mathbf{R p})\end{array}$ & $\begin{array}{c}\text { Jumlah } \\
\text { Harga } \\
\text { (Rp) }\end{array}$ \\
\hline 1 & Hati batang pisang & 10 & Buah & 20.000 & 200.000 \\
\hline 2 & Gas LPG 3kg & 1 & Buah & 19.000 & 19.000 \\
\hline 3 & Tepung Tapioka (Kanji) & 10 & $\mathrm{Kg}$ & 10.000 & 100.000 \\
\hline 4 & Bawang Merah & 1 & $\mathrm{Kg}$ & 18.000 & 18.000 \\
\hline 5 & Bawang Putih & 1 & $\mathrm{Kg}$ & 18.000 & 18.000 \\
\hline 6 & Garam & 2 & $\mathrm{Kg}$ & 10.000 & 20.000 \\
\hline 7 & Penyedap Rasa & 500 & Gram & 15.000 & 15.000 \\
\hline 8 & Bumbu Bubuk (Keju, BBQ, Pedas) & 3 & Pack & 5.000 & 15.000 \\
\hline 9 & Plastik Ukuran $1 \mathrm{~kg}$ & 2 & Pack & 17.000 & 34.000 \\
\hline 10 & Label & 2 & Lembar & 10.000 & 20.000 \\
\hline 11 & Minyak Goreng & 2 & Liter & 14.000 & 28.000 \\
\hline 12 & Air dan Listrik & 1 & Bulan & 100.000 & 100.000 \\
\hline 13 & Tepung Terigu & 10 & $\mathrm{Kg}$ & 9.000 & 90.000 \\
\hline \multirow[t]{7}{*}{14} & Tenaga Kerja & & & & \\
\hline & a. Membelah bahan dan mencuci & 1 & Jam & 7.500 & 7.500 \\
\hline & Pembuatan adonan & 1 & Jam & 7.500 & 7.500 \\
\hline & Pengukusan & 1 & Jam & 7.500 & 7.500 \\
\hline & Pengeringan & 1 & Jam selama 2 hari & 7.500 & 15.000 \\
\hline & Penggorengan & 2 & Jam & 7.500 & 15.000 \\
\hline & f. Pengemasan dan Penempelan label & 2 & Jam & 7.500 & 15.000 \\
\hline 15 & Transportasi & 1 & Sekali Antar & 20.000 & 20.000 \\
\hline \multicolumn{5}{|c|}{ TOTAL BIAYA VARIABEL } & 564.700 \\
\hline
\end{tabular}

Sumber: Analisis Primer

Keterangan : $1 \mathrm{HOK}=8$ jam/ hari (Rp. 60.000)

Analisis Perhitungan

a. Total Biaya $=$ Biaya Tetap + Biaya Variabel

$$
\begin{aligned}
& =\text { Rp. } 33.330+\text { Rp. } 564.700 \\
& =\text { Rp. } 598.030
\end{aligned}
$$

b. Penerimaan $=$ Harga/bungkus $\mathrm{x} \mathrm{Jml}$ produksi

\section{Rincian :}

Total produksi $=100$ bungkus $/ 200$ gram

Penjualan kerupuk hati pisang dibagi menjadi 2 yaitu kerupuk A (Mentah) dan kerupuk B (Matang). Kerupuk A seharga Rp. 10.000/ bungkus (200 gram) dengan berbagai varian rasa yaitu keju, BBQ dan pedas. Kerupuk B seharga Rp. 8.000/ bungkus (200 gram).

Kerupuk A $=$ Rp. 10.000

Kerupuk B = Rp. 8.000

Penjualan Kerupuk A = 60 bungkus x Rp.

$$
10.000=\text { Rp. } 600.000
$$

Penjualan Kerupuk B $=40$ bungkus x Rp.

$8.000=$ Rp. 320.000

Total penerimaan $=$ Rp. 920.000 c. Pendapatan $=$ Penerimaan - Total Biaya

$$
\begin{aligned}
& =\text { Rp. } 920.000-\text { Rp. } 598.030 \\
& =\text { Rp. } 321.970
\end{aligned}
$$

Tabel 3. Analisis Rugi Laba

\begin{tabular}{ll}
\hline Jenis Biaya & Jumlah \\
\hline Biaya Tetap & Rp. 33.330 \\
Biaya Variabel & Rp. 564.700 \\
Hasil Penjualan & Rp. 920.000 \\
Total Pendapatan & \\
(Hasil Penjualan - & \\
Biaya Produksi ) & Rp. 321.970 \\
\hline
\end{tabular}

Analisis Perhitungan :

a. R/C Ratio $=\frac{\text { Penerimaan }}{\text { Total Biaya }}$

$$
\begin{aligned}
& =\frac{\text { Rp.920.000 }}{\text { Rp.598.030 }} \\
& =1,53(\text { R/C Ratio }>1=\text { layak). }
\end{aligned}
$$

Rata-rata nilai $\mathrm{R} / \mathrm{C}$ Ratio yaitu 1,53 yang artinya bahwa usaha tersebut layak untuk diusahakan dan dikembangkan karena 
untuk setiap $\mathrm{Rp} 1,00$ biaya yang di keluarkan akan menghasilkan penerimaan sebesar $\mathrm{Rp} 1,53$ dan mengalami keuntungan

b. B/C Ratio $=\frac{\text { Pendapatan }}{\text { Total Biaya }}$

$$
\begin{aligned}
& =\frac{\text { Rp. } 321 \cdot 970}{\text { Rp. } 598 \cdot 030} \\
& =0,53(\mathrm{~B} / \mathrm{C} \text { Ratio }>0=\text { layak }) .
\end{aligned}
$$

Nilai B/C Ratio > 0 yaitu 0,53 artinya layak untuk diusahakan dan dikembangkan, yang berarti keuntungan yang diperoleh lebih besar dari biaya yang dikeluarkan.

c. Analisis ROI dinyatakan dalam \% dengan rumus sebagai berikut:

Return Of Investment (ROI)

$=\frac{\text { Total Penjualan }- \text { Investasi }}{\text { Investasi }} \times 100 \%$

$=\frac{\text { Rp. } 920.000-\text { Rp. } 598.030}{\text { Rp.598.030 }} \times 100 \%=53,83 \%$

d. BEP (Rp) Totalitas

Alasan menggunakan BEP Totalitas yaitu untuk menghitung 2 harga penjualan yang berbeda tetapi masih dalam satu kesatuan usaha.

$$
\begin{aligned}
\mathrm{BEP}(\mathrm{Rp}) \text { Totalitas } & =\frac{F C}{1-\frac{V C}{S}} \\
& =\frac{\text { Biaya Tetap }}{1-\frac{\text { Biaya Variabel }}{\text { Penerimaan }}} \\
& =\frac{R p .33 .330}{1-\frac{R p \cdot 564.700}{R p .920 .000}} \\
& =\frac{R p \cdot 33.330}{0,3861} \\
& =\mathrm{Rp} .86 .324
\end{aligned}
$$

Sales mix (nilai produksi) =

Penerimaan kerupuk A : Penerimaan kerupuk B

$$
\begin{aligned}
& =\text { Rp. } 600.000: \text { Rp. } 320.000 \\
& =600: 320
\end{aligned}
$$

Total perbandingan nilai produksi $=600+32$

$$
=920
$$

1) BEP Penerimaan Kerupuk $A$

$$
\begin{aligned}
& =\frac{\text { Nilai Produksi }}{\text { Total Produksi }} \times \text { BEP Totalitas } \\
& =\frac{600}{920} \times R p .86 .324 \\
& =\text { Rp. } 56.298
\end{aligned}
$$

BEP Produksi Kerupuk A

$$
\begin{aligned}
& =\frac{B E P \text { Peneriaan }}{\text { Harga Jual }}=\frac{R p .56 .298}{R p \cdot 10.000} \\
& =6 \text { bungkus } / 200 \text { gram }
\end{aligned}
$$

Artinya, penjualan kerupuk A akan mengalami BEP pada saat usaha mendapatkan penerimaan sebesar Rp. 56.298 atau sebanyak 6 bungkus/ 200 gram kerupuk A. Pada penjualan kerupuk A bungkus ke 7 maka mulai mendapatkan keuntungan

2) BEP Penerimaan Kerupuk B

$$
\begin{aligned}
& =\frac{\text { Nilai Produksi }}{\text { Total Produksi }} \times \text { BEP Totalitas } \\
& =\frac{320}{920} \times \text { Rp. } 86.324 \\
& =\text { Rp. } 30.025
\end{aligned}
$$

BEP Produksi Kerupuk B

$$
\begin{aligned}
& =\frac{B E P \text { Penerimaan }}{\text { Harga Jual }}=\frac{R p .30 .025}{R p .8 .000} \\
& =4 \text { bungkus } / 200 \text { gram }
\end{aligned}
$$

Artinya, penjualan kerupuk B akan mengalami BEP pada saat usaha mendapatkan penerimaan sebesar Rp. 30.025 atau sebanyak 4 bungkus/ 200 gram kerupuk B. Pada penjualan kerupuk B bungkus ke 5 maka mulai mendapatkan keuntungan

Berdasarkan analisis ekonomi tersebut, maka usaha kerupuk batang hati pisang layak diusahakan.

\section{KESIMPULAN}

1. Kecamatan Jenawi merupakan sentra produksi tanaman pisang tetapi pemanfaatan hati batang pisang belum ada.

2. Metode yang digunakan adalah partisipasi masyarakat (participatory rural appraisal) yang menekankan pada inovasi dan teknologi dalam pembuatan kerupuk 
hati batang pisang/ares dengan menggunakan teknologi sederhana.

3. Untuk menghasilkan kerupuk $20 \mathrm{~kg}$ membutuhkan biaya tetap produksi sebesar Rp. 33.330,- dan biaya variabel sebesar Rp. 564.700,-.

4. Total penerimaan dari kerupuk $20 \mathrm{~kg}$ sebesar Rp. 920.000,- sehingga total pendapatan sebesar Rp. 321.970,-.

5. Nilai R/C Ratio yaitu 1,53 (layak), nilai B/C Ratio yaitu 0,53 (layak). Sehingga berdasarkan analisis ekonomi, usaha kerupuk hati batang pisang atau kerupuk ares layak untuk diusahakan dan dikembangkan.

\section{DAFTAR PUSTAKA}

Direktorat Jenderal Hortikultura. 2015. Statistik Produksi Hortikulrtura Tahun 2014. Direktorat Jenderal Hortikultura. Kementerian Pertanian. Jakarta

Kementerian Pertanian. 2016. Outlook Komoditas Pertanian Sub Sektor Hortikultura Pisang. Pusat Data dan Sistem Informasi Pertanian. Kementerian Pertanian. Jakarta.

Anonim. 2015. 12 Manfaat Pohon Pisang Bagi Kehidupan Manusia. Manfaat.co.id/manfaat-pohon- pisang. Diakses : Kamis, 16 Februari 2017

Afandi M. 2013. Kesehatan Serta Cara Penggunaannya.

http://www.munsypedia.com/2013/12/ manfaat-buah-kulit-batang-hatiakar.html. Diakses : Kamis, 16 Februari 2017.

Redaksi Trubus. 2006. Berkebun Pisang secara Intensif. Penebar Swadaya. Jakarta

Suyanti dan A. Supriyadi. 2008. Pisang, Budidaya, Pengolahan dan Prospek Pasar. Penebar Swadaya. Jakarta. 132p

Mujiyo, M., Widijanto, H., Herawati, A., Rochman, F., \& Rafirman, R. 2017. Potensi Lahan untuk Budidaya Pisang di Kecamatan Jenawi Karanganyar. Caraka Tani: Journal of Sustainable Agriculture. 32(2), 142- 148 . doi: http://dx.doi.org/10.20961/carakatani.v 32i 2.17020 